\title{
EXPORT EFFICIENCY OF THE FISH PROCESSING INDUSTRY IN NORTH SULAWESI
}

\author{
Victor P.H. Nikijulu w", Riyanto Basuki", \\ Daniel R. Monintja"*), and John Haluan"t)
}

\begin{abstract}
Processed fish products are international trade items which constitute a considerable portion of North Sulawesi province's export earnings. The first five commodities are fresh tuna, canned tuna, frozen tuna, frozen malalugis, and katsuobushi. This study was performed in order to understand the relative efficiencies of production of these commodities. The nominal protection coefficient (NPC) and domestic resource cost (DRC) as indicators of comparativeness and competitiveness were estimated for each commodity. The findings showed that fresh tuna, frozen malalugis, and katsuobushi were produced efficiently while canned tuna and frozen tuna were manufactured under inefficient production structures. Future development of fresh tuna, frozen malalugis, and katsuobushi should be accompanied by market diversification. Efficient production of canned and frozen tuna, could be achieved by increasing the processing capacity of the industry.
\end{abstract}

\section{KEYWORDS: Processing industry, production efficiency.}

\section{INTRODUCTION}

Outward looking policy" is a term currently used to denote economic policy of a country which promotes export and reduces import (Corden, 1974). To implement an outward looking policy, a country should consider foreign consumers as its target market. Goods and services produced locally are directed to meet the demand of both the domestic and foreign consumers. In order that a locally-produced item can successfully enter the international market, it should be efficiently produced and of superior quality (Salvatore, 1987).

There are various methods to measure the production efficiency of export goods. One method is to compare the domestic price of the item with its international (border) price. If the domestic price is lower than the border price, it can be said that domestic production is more efficient than the international standard (Tsakok, 1990). Another method is to measure the comparative advantage in producing that item. If production of the item has a comparative advantage, the production should be continued as it can save foreign exchange.
This study aim to measure production efficiency of the fish processing industry in North Sulawesi province. The industry produces fishery commodities for local and international markets. North Sulawesi province produces several kinds of fishery commodities. For instance in 1994, there were 29 fisheries commodities which were exportable. They were grouped into seven categories; canned fish, frozen fish, fresh fish, tuna loin (boneless fish), dried fish, live fish, and smokedgrilled fish. The export of fisheries commodities from North Sulawesi increased very rapidly from 4,362 ton in 1989 to 23,985 in 1994 . The corresponding value of the exports rose from US\$ 5.1 million in 1989 to US\$ 51.7 in 1994 . The number of transactions in the export market reached 1,493 times in 1994, a ninefold increase from 168 transactions in 1989.

Although total exports increased, some export items have declined. For instance, the export of canned tuna which reached 5.7 ton in 1994 decreased to 4.1 ton in 1995. Similarly, the export of frozen skipjack went down to 1.7 ton in 1995, from 2.8 ton in 1990. Reduced exports may be attributed to inefficiency of domestic production processes. Thus there is a need to examine the

\footnotetext{
*) Researcher of the Research Institute for Marine Fisheries (RIMF), Jakarta

**) Fisheries Faculty, Bogor Agricultural University
} 
fish processing industry in North Sulawesi in order to measure its economic comparativeness and competitiveness.

\section{METHOD OF THE STUDY}

Based on the export values, five main com. modities were selected for analysis. These were fresh tuna, canned tuna/skipjack, frozen tuna/ skipjack, frozen malalugis, and grilled-smoked skipjack (katsuobushi). These five commodities together contributed about $45 \%$ of the 1994 export value.

Interviews were carried out to collect primary data from the processing industry in North Sulawesi, particularly in Bitung and Manado. The information from these interviews was supported by data gleaned from companies annual reports and balance sheets. It is common in industrial surveys that collecting business data, especially those of financial matters, is extremely difficult. If firms do not object to sharing their data, it does not mean that the data can be accepted automatically as accurate. Keeping this in mind, this study dealt much more with data quality than quantity. In total, only 15 firms were interviewed. They consisted of two canning factories, four freezing companies, six katsuobushi-producing firms, and three firms which export fresh tuna.

The economic performance of this processing industry was simply analyzed by estimating the Nominal Protection Coefficient (NPC) and Domestic Resource Cost (DRC). The NPC was estimated by equation 1 (Tsakok, 1990).

$$
N P C_{i}=\frac{P_{i}^{d}}{P_{i}^{b}}
$$

where: $\quad P^{d}=$ domestic price

$P^{b}=$ border price, namely foreign price times exchange rate. Thus the border price is the foreign price in domestic currency.

$\mathrm{I}=$ commodity $\mathrm{I}$.

\footnotetext{
If $\mathrm{NPC}>1$, the industry receives positive protection or domestic production is inefficient;
}

(2) If $\mathrm{NPC}=1$, the structure of protection is neutral and there is no difference between the efficiencies of domestic and foreign firms;

(3) If $\mathrm{NPC}<1$, the domestic production is efficient and increased export of the product may be consid. ered.

The NPC can be estimated for the whole fisheries sector $\left(\mathrm{NPC}_{\mathrm{g}}\right)$ (Tsakok, 1990).

$$
N P C_{s}=\sum_{i=0}^{m}\left(C_{i}\right)\left(N P C_{i}\right)
$$

where: $\quad C_{i}=$ share or contribution of commodity $\mathrm{i}$ $\mathrm{m}=$ number of commodity.

The DRC is calculated as equation (3) (Tsakok, 1990).

$$
D R C_{i}=\frac{\sum_{j=k+1}^{n} a_{i j} V_{j}}{P_{i}^{b}-\sum_{j=1}^{k} a_{i j} P_{j}^{b}}
$$

where: $a_{i j}, 1$ to $k=$ coefficients for traded inputs $j$ to produce good i.

$a_{i j}, k+1$ to $n=$ coefficients for domestic resource or non traded input $j$ to produce good $\mathrm{i}$.

$\mathrm{V}, j=$ shadow price of domestic resource or non-traded input

The DRC can assume a range of numerical values. A ranking of DRCs by these values is indicative of varying levels of efficiency of domestic production or of its international competitiveness. DRC $<1$ indicates efficiency and international competitiveness.

\section{RESULTS AND DISCUSSIONS}

In this study, efficiency was measured at business gate level. The domestic price at this level is the retail price after deducting transfer costs needed to bring the commodity from the firm to the retail market. An average retail price 
was calculated for each commodity. Fresh tuna, frozen malalugis, and frozen tuna were rated at

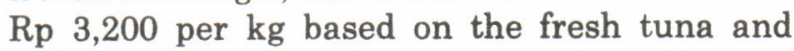
malalugis prices. As there was no domestic market for katsuobushi, its domestic value was estimated by taking the price of traditionallyprocessed-smoked tuna (cakalang fufu) of $\mathrm{Rp}$ 4,000 per $\mathrm{kg}$. The domestic price of canned tuna was $\operatorname{Rp} 79,200$ per box, equivalent to $R p 1,650$ per small can of 185 gram gross weight or about Rp8,920 per kg (Table 1).

The border prices of the commodities were the export prices in domestic currency. Table 1 shows the border prices at export point and their adjusted prices at business level. It can be seen that fresh tuna and katsuobushi had relatively higher prices. The NPCs for fresh tuna, frozen malalugis, and katsuobushi were less than one, whereas those for canned tuna and frozen tuna were greater than one (Table 1). The coefficients reveals that under the existing economic condition and industrial structure, producers of fresh tuna, frozen malalugis and katsuobushi had the capability to compete successfully with foreign producers. On the other hand, the producers of canned tuna and frozen tuna were preserved by current industrial structures and economic conditions which imply that their production organizations were inefficient.

Protecting an industry such as tuna canning can be accepted in the short run (Krueger, 1974). Developing or infant industries are commonly protected. The infant industry may be protected, but once it has been developed, the protection structure should be gradually reduced until there is no protection at all. Industry must be expected to run efficiently and without protection as protection causes domestic consumers to pay higher prices and causes long term economic losses (Krueger, 1985).

Since the production of both canned and frozen tuna were inefficient, attempts should be made to improve these situations. Field surveys disclosed that the canning factories operated at only $40 \%$ of their technical capacities and freezing factories lacked raw materials as their fishing fleet did not operate optimally. These shortcomings are areas in which to improve production process.

Table 1. Domestic price, border price, and nominal protection coefficient (NPC) of exportable fisheries products from North Sulawesi, 1994.

\begin{tabular}{|c|c|c|c|c|c|c|}
\hline \multirow{2}{*}{ Commodity } & \multirow{2}{*}{$\begin{array}{c}\text { Domestic } \\
\text { Price (Rp) }\end{array}$} & \multicolumn{3}{|c|}{ Border Price } & \multirow[b]{2}{*}{ NPC } & \multirow{2}{*}{$\begin{array}{l}\text { Export } \\
\text { Share }\end{array}$} \\
\hline & & US \$ & $\mathbf{R p}$ & $\begin{array}{c}\text { Adjusted } \\
\text { (Rp) }\end{array}$ & & \\
\hline Fresh tuna (kg) & 3,200 & 4,73 & 10,406 & 10,390 & 0,31 & 0,34 \\
\hline Canned tuna (kg) & 8,920 & 2,49 & 5,563 & 5,545 & 1,61 & 0,31 \\
\hline Frozen Malalugis (kg) & 3,200 & 2,06 & 4,532 & 4,532 & 0,70 & 0,18 \\
\hline Frozen tuna/skipjack & 3,200 & 0,91 & 4,532 & 2,002 & 1,60 & 0,10 \\
\hline Katsuobushi & 4,000 & 4,47 & 9,834 & 9,834 & 0,41 & 0,06 \\
\hline
\end{tabular}

US $\$ 1.00=\operatorname{Rp} 2,200$.

Inefficiency of canning and freezing factories could be regarded as a resultant of the whole fisheries business performance. A study on this aspect in North Sulawesi revealed that five components needed to be strengthened in order to develop a competitive fishery sector. Those components were the availability of infrastructure, the supply of input factors such as clean water, oil and fish as raw materials, processing, marketing, and institutional guidance. 
The only component that seemed to welldeveloped and under full control of the local producers was production or fishing activity (DGF, 1996).

The estimate nominal protection coefficient for the whole fishery sector was 0,92 . (Table 1 ). This was an indication that the fishery sector had a reasonably efficient production structure. It was attributable to the fact that inefficient production processes of some commodities were compensated for by the efficiency of processes in some other commodities.

Based on the costs of the non-traded and traded inputs, the coefficients of DRC were estimated (Table 2). The DRCs for canned tuna and frozen tuna were greater than one, indicating their inefficiency in utilizing domestic resources. According to Table 2, to yield US\$ 1.00 as export earnings, canned tuna and frozen tuna industries have to spend $R p 2,383$ and $R p 3,037$, respectively for their domestic resource use. In other words, the shadow prices of domestic inputs were valued higher than the revenue derived from selling the outputs on international market. In contrast, the DRCs of fresh tuna, frozen malalugis and katsuobushi were less than one, meaning that their production was efficient.

The findings of DRC and NPC analysis complemented each other. Hence, both showed that production of fresh tuna, frozen malalugis, and katsuobushiwere efficient, whereas production of canned tuna and frozen tuna were inefficient. Looking at the production technologies, it is clear that efficient production was attained by traditionally or semi-traditionally processed products. Consequently, development of traditional fish processing technologies should be prioritized.

Table 2. Costs of non-traded and traded inputs, international value added,and domestic resource costs of exportable commodities from North Sulawesi, 1994.

\begin{tabular}{|c|c|c|c|c|c|c|}
\hline \multirow{2}{*}{ Commodity } & \multirow{2}{*}{$\begin{array}{c}\text { Nominal } \\
\text { Cost of non } \\
\text { traded in- } \\
\text { puts } \\
(\mathrm{Rp} / \mathrm{kg})\end{array}$} & \multirow{2}{*}{$\begin{array}{l}\text { Marginal } \\
\text { opportu- } \\
\text { nity cost of } \\
\text { non traded } \\
\text { input } \\
(\mathrm{Rp} / \mathrm{kg})\end{array}$} & \multirow{2}{*}{$\begin{array}{c}\text { Cost of } \\
\text { traded in- } \\
\text { put }(\$ / \mathrm{kg})\end{array}$} & \multirow{2}{*}{$\begin{array}{c}\text { Interna- } \\
\text { tional } \\
\text { added val- } \\
\text { ues }(\$ / \mathbf{k g})\end{array}$} & \multicolumn{2}{|c|}{$\begin{array}{c}\text { Domestic Resource Cost } \\
\text { (DRC) }\end{array}$} \\
\hline & & & & & $\mathbf{R p} / \$ 1$ & Coefficient \\
\hline Fresh tuna & 4,054 & 3,443 & 0.07 & 4.66 & 739 & 0.34 \\
\hline Canned tuna & 2,373 & 2,058 & 1.65 & 7.60 & 2,383 & 1.08 \\
\hline $\begin{array}{l}\text { Frozen } \\
\text { Malalugis }\end{array}$ & 2,863 & 2,490 & 0.09 & 1.97 & 1,264 & 0.57 \\
\hline $\begin{array}{l}\text { Frozen tuna/ } \\
\text { skipjack }\end{array}$ & 2,863 & 2,490 & 0.09 & 0.82 & 3,037 & 1.38 \\
\hline Katsuobushi & 3,527 & 3,021 & 0.49 & 3.98 & 759 & 0.34 \\
\hline
\end{tabular}

International value added is derived by substracting costs of traded inputs from border price.

Problems may be anticipated, however, if markets for these traditional products are taken into consideration. Evaluation showed that although fresh tuna was sent to seven countries, Japan dominated $98 \%$ of the market. The frozen malalugis was only sold to two countries, and again Japanese market accounted for 97\%. Moreover, Japan was the only export destination for katsuobushi. Hence, markets for these traditional products tended to be monopsonies. Under such market structures, further development of the products will be dictated by the buyers' preferences. Another perspectve would be to say that if there is no attempt to diversify the market, further development of these traditional products is not so promising. 
Though products resulting from modern fish processing technologies were shown here to be inefficient, their markets were more competitive. Canned tuna, for instance, was marketed to 14 countries, with the USA, as the biggest market for the product, accounting for $61 \%$. If the production structure can be managed properly by increasing the utilization of processing capacity (Neary, 1978), unit cost may be reduced and efficiency will be improved.

\section{CONCLUSION AND RECOMMENDA- TION}

Of five main fisheries commodities in North Sulawesi province, canned and frozen tuna were not efficiently produced. Production of fresh tuna, frozen malalugis and katsuobushi were efficient despite traditional processing technologies being used and markets for these three products were limited.

Future development of fresh tuna, frozen malalugis, and katsuobushi exports should be based on the market intelligence analyses, that is, seeking additional market destinations and understanding the position of competitors. Since producers of these products are small enterprises, they are likely unable to do market intelligence analyses themselves. The local government, through the Provincial Coordinating Investment Board (BKPM) and the Trade Services (Kanwil
Perdagangan) should take responsibility for these analyses.

In order to improve production efficiency of canned tuna and frozen tuna, unit cost should be reduced by increasing utilization of the existing processing capacity. Development of new canning factories are not recommended.

\section{REFERENCES}

Corden, W.M. 1974. Trade policy and economic welfare. Oxford University Press. London. 423 p.

DGF, 1996. Proyek Pembangunan Usaha Perikanan. Pekerjaan Pengembangan Agribisnis Perikanan di Bitung, Sulawesi Utara, Dalam Kaitannya Dengan Pengembangan BIMP-EAGA. Direktorat Jenderal Perikanan (Unplublished report).

Krueger, A.O. 1974. The political economy of the rentseeking society. American Economic Review, 64(3):291-303.

Krueger, A. O. 1985. Import substitution versus export promotion. Finance and Development, June 1985: 20-23.

Neary, J.P. 1978. Short-run capital specificity and the pure theory of international trade. Economic Journal, 88:488-510.

Salvatore, D. 1987. International Economics. Macmillan Publishing Company, New York. 611 p.

Tsakok, I. 1990. Agricultural Price Policy. A Practitioner's Guide to Partial Equilibrium Analysis. Cornell University Press. Ithaca and London. 305 p. 